Ann. Rept. Kansai PI. Prot. (58): 7-12 (2016)

\title{
コナガ発生予察用フェロモン剂に特異的に誘引された 非標的チョウ目昆虫
}

\author{
河野勝行・飯田博之・武田光能・本多健一郎 \\ Katsuyuki Kohno, Hiroyuki Iida, Mitsuyoshi Takeda and Ken-ichiro Honda: \\ Non-target lepidopteran insects specifically attracted to a sex pheromone lure \\ for Plutella xylostella Linnæus (Lepidoptera: Plutellidae)
}

\begin{abstract}
Sex pheromone lures usually attract the target species very specifically; however, non-target species are often also specifically attracted. Non-target species attracted to a sex pheromone lure could lead to technical problems in pest monitoring, for example in counting mechanically. In this study, non-target lepidopteran species specifically attracted to the sex pheromone lures for the diamondback moth, Plutella xylostella (Linnæus) were examined in four open fields in Tsu City, Mie, Japan. In addition to specific attraction by the target species, six (Acrolepiopsis sapporensis (Matsumura), Microchilo inouei Okano, Glyphipterix nigromarginata Issiki, Eupsilia tripunctata Butler, Orthosia lizetta Butler, Anorthoa angustipennis (Matsumura)) lepidopteran species were specifically attracted to the lures for P. xylostella. Among these, A. sapporensis, M. inouei and G. nigromarginata were considered to be the species susceptible to be erroneous determination when P. xylostella are counted mechanically.
\end{abstract}

緒
コナガ Plutella xylostella 菜類の害虫であり, 性フェロモンが明らかにされたこ とにより（Tamaki et al., 1977 ; Koshihara et al., 1978 ; Ando et al., 1979), 性フェロモン誘引剂を利用した発 生予察が行われている(本郷，2010）。しかしながら， コナガ用誘引率にはネギコガ Acrolepiopsis sapporensis (Matsumura), ナガイモコガ Acrolepiopsis nagaimo Yasuda, シバツトガ Parapediasia teterella（Zincken）などの非標 的種が誘引されることが知られている（豊嶋，2010）。

フェロモン剂に非標的種が誘引されても，慣れた者 による目視調査が行われれば問題は少ないが（本郷, 2010), 同定に不慣れな者が調査する場合や, 機器を利 用して自動的に計数する場合には誤りや誤差が生じる可 能性が高い。筆者らはこれまでに，ヨトウガ Mamestra brassicae (Linnæus), タマナギンウワバ Autographa nigrisigna Walker, ハス モンヨトウ Spodoptera litura (Fabricius), オオタバコガ Helicoverpa armigera (Hübner), タバコガ H. assulta（Guenée）の発生予察用フェロモン 剂について, 特異的に誘引される非標的チョウ目昆虫の
種類相と, その季節消長について明らかにし, これらの チョウ目種のフェロモン剂を使用する際の問題点につ いて検討した（河野・飯田，2012a，b，2013; 河野ら, 2014 ; 河野, 2015). ここでは, これら一連の調査の中で, コナガ発生予察用フェロモン剂に特異的に誘引される非 標的チョウ目昆虫の種類相とその季節的消長を明らかに することにより，コナガの発生予察の現場を念頭におい たフェロモントラップへの非標的種の混入に関わる問題 を検討する。

本文に先立ち，発生予察用フェロモン剂に関する資料 をご提供いただいた信越化学工業株式会社の望月文昭博 士, チョウ目昆虫の同定についてご教示いただいた国立 科学博物館の神保宇嗣博士, 調査戋場をご提供いただい た田原口充貞氏および橋本力男氏に打礼申し上げる。ま た, この研究の一部は, 農林水産省委託事業「発生予察 の手法検討委託事業（発生予察調査実施基準の新規手法 策定事業)」の予算で実施した.

\section{材料および方法}

調査場所は, 三重県津市安濃町草生の野菜茶業研究所

農業・食品産業技術総合研究機構野菜茶業研究所 NARO Institute of Vegetable and Tea Science（現：農業・食品産業技術総合研究機 構野菜花き研究部門 Institute of Vegetable and Floriculture Science, NARO) 2016年 1 月19日受理 
内キャベツ國場（調査地点 A : くさわ）と，津市庄田町 (同 B：しょうだちょう), 津市一志町高野 (同 C : たか の), 津市一志町大仰（同 D：おおのき）のキャベツ围 場を含んだ 3 か所の有機栽培の野菜類围場の合計 4 か所 である。これらの場所は，キャベツが作付けされていな い時期には裸地になっていたか（A)，他の野菜類が作 付けされており（B, C, D)，大仰（D）ではトラップの 近くに混入する種として既知のネギコガの寄主植物であ るネギやタマネギが栽培されていた時期があった，以上 4 か所の戋場の中あるいは近傍に，オオタバコガ，コナ ガ，タマナギンウワバ，八スモンヨトウ，ヨトウガ，タ バコガの合計 6 種類の発生予察用フェロモン剂（コナガ 用は住友化学製の $\mathrm{PX}^{\circledast}$ で，その他はサンケイ化学製； いずれも日本植物防疫協会より購入)を白色の SEトラッ プ®（サンケイ化学製）に装着した粘着板の中央に設置 し，それぞれのトラップを約 $5 \mathrm{~m}$ 間隔で上記の順番に 地上約 $40 \mathrm{~cm}$ の高さで直線状に配置した．調査地点内の 位置のローテーションは行わなかった，上記トラップは 2008年 8 月 26 日（タバコガ用は 2011 年 6 月 1 日）に設置 し，その後ほぼ 1 週間ごとに粘着板を交換し，捕獲され たチョウ目昆虫を同定し計数した。フェロモン剂は，ほ ぼ 4 週間ごとに交換した。オオタバコガ用，タマナギン ウワバ用，ハスモンヨトウ用，ヨトウガ用，タバコガ用 トラップは，本来それぞれの種のそれぞれの戋場に扔け る発生動向を把握するために設置したが，本研究におい ては，誘引の特異性について判断するためのデータとし て活用した。

解析の対象は，調查期間を通した全ての調査地点にお いてコナガ用トラップにおける合計の捕獲個体数が 5 頭 以上だったチョウ目昆虫種とした。特異的に捕獲された かどうかの判断は，それぞれの調査地点に打けるある チョウ目昆虫種が， 6 種（2011年 6 月以前は 5 種）の発 生予察用フェロモン剂を使用したトラップのいずれかに ランダムに捕獲される（どのトラップにも同じ確率で捕 獲される）と仮定した場合と比較して，危険率 1\%ある いは 5\%とした Pearson のカイ二乗検定（それぞれの調 查地点のコナガ用トラップでの合計捕獲個体数が10頭よ り多かった場合)あるいは二項検定(同じく10頭以下だっ た場合）で，特定のトラップに有意に多く捕獲されたか どうかを基準とした。

コナガ発生予察用フェロモン剂は (Z)-11-Hexadecenal と (Z)-11-Hexadecenyl Acetate と (Z)-11-Hexadecen-1-ol の $50: 50: 1$ の混合物 $0.1 \mathrm{mg}$ をゴムキャップに染み 込ませたものである (本郷，2010)。このうち (Z)-11Hexadecenal はオオタバコガ用フェロモン剂の主成分で
あり（Kehat and Dunkelblum，1990 ; 本郷，2010)，タバ コガ用フェロモン剤（Sugie et al., 1991b ; 本郷， 2010） とヨトウガ用フェロモン剂（杉江ら，1993；本郷，2010） の微量成分である。また，(Z)-11-Hexadecenyl Acetate は ヨトウガ用フェロモン剂（杉江ら，1993；本郷，2010） の主成分である。(Z)-11-Hexadecen-1-ol は，ここで使用 した他のフェロモン剤との共通成分はない。 また，タマ ナギンウワバ発生予察用フェロモン剂の成分（Sugie et al., 1991a ; 本郷, 2010) とハスモンヨトウ発生予察用フェ ロモン剂の成分（Yushima et al., 1974 ; 本郷，2010）に は，コナガ用フェロモン剂との共通成分はない.

この報告では調査開始から約 4 年半を経過した2013年 3 月 6 日までの結果を報告する。 また，ネギコガとナガ イモコガについて，粘着板に付着した個体を同定識別す ることは困難だったので，十ガイモコガも捕獲されてい た可能性もあるが，すべてネギコガとして扱った。

\section{結果}

コナガ用トラップに 5 頭以上捕獲されたチョウ目昆 虫は30種であった（Table 1). Table 1 には，それぞれの 種の捕獲個体数と捕獲されたコナガの個体数に対する 比率，開張，コナガに対する大まかな相対的な大きさ を示し，捕獲個体数が多かった順に並べた。これらの うち，コナガ用トラップに有意に多く捕獲された 10 種, コナガ用フェロモン剤に誘引されるという報告がある シバツトガ（豊嶋，2010），使用したそれぞれの誘引剂 の標的種について, それぞれの調査地点 $\mathrm{A}, \mathrm{B}, \mathrm{C}, \mathrm{D}$ ごとのそれぞれのフェロモン剂を誘引源とした捕獲数 (n1:n2:n3:n4:n5:n6 ; n1 はコナガ用, n2 はオオタバコガ 用, n3 はタバコガ用, n4 はヨトウガ用, n5 はタマナギ ンウワバ用, n6 は八スモンヨトウ用のトラップにおけ る捕獲個体数）を Table 2 に示した。 それぞれの調查地 点で有意に多く捕獲されたものは太字（危険率 1\%）あ るいは斜体（危険率 5\%）で示した，また，それぞれの 種の捕獲時期も併せて示した.

コナガ，ネギコガ，チビツトガ，ヘリグロホソハマキ モドキ, クロミミキリガ，ミツボシキリガ，ホソバキリ ガの 7 種はいずれの調査地点においても，有意に多くコ ナガ用トラップに捕獲された。クロネハイイロヒメハマ キは調查地点 $\mathrm{A}, \mathrm{B}$ に打いて, オオシラナミアツバは調 查地点 $\mathrm{D}$ に扔いて, ギシギショトウは調査地点 $\mathrm{B}$ におい て有意に多くコナガ用トラップに捕獲された，オオシラ ナミアツバは2010年 8 月11日の調査のときに全26頭のう ち24頭が調查地点 D のコナガ用トラップで捕獲された. シバツトガはいずれの調査地点においてもオオタバコ 
Table 1. List of lepidopteran species (the scientific name and the trivial name in Japanese) ${ }^{\text {a) }}$ captured by sticky traps containing the attractant for Plutella xylostella, with their total captured numbers, ratios to the number of $P$. xylostella, wing expanses, and relative sizes compared with $P$. xylostella.

\begin{tabular}{|c|c|c|c|c|c|}
\hline Species & 和名 & Captured Number & Ratio & Wing Expanse $(\mathrm{mm})^{\mathrm{b}, \mathrm{c}, \mathrm{d}, \mathrm{e})}$ & Relative Size \\
\hline Plutella xylostella & コナガ & 5896 & 1.000 & $10-16^{c)}$ & (target species) \\
\hline Acrolepiopsis sapporensis & ネギコガ & 3854 & 0.654 & $10-13^{\mathrm{c})}$ & similar \\
\hline Microchilo inouei & チビツトガ & 332 & 0.056 & $9-13^{\mathrm{d})}$ & similar \\
\hline Spodoptera litura & ハスモンヨトウ & 140 & 0.024 & $38-40^{\mathrm{b})}$ & much larger \\
\hline Spoladea recurvalis & シロオビノメイガ & 101 & 0.017 & $16-22^{\mathrm{d})}$ & larger \\
\hline Glyphipterix nigromarginata & ヘリグロホソハマキモドキ & 94 & 0.016 & $10-12^{\mathrm{c})}$ & similar \\
\hline Orthosia lizetta & クロミミキリガ & 82 & 0.014 & $30-38^{\mathrm{b})}$ & much larger \\
\hline Eupsilia tripunctata & ミツボシキリガ & 61 & 0.010 & $35-39^{b)}$ & much larger \\
\hline Rhopobota naevana & クロネハイイロヒメハマキ & 50 & 0.008 & $11-23^{\mathrm{d})}$ & similar \\
\hline Nola taeniata & クロスジシロコブガ & 36 & 0.006 & $11-14^{\mathrm{b})}$ & similar \\
\hline Hipoepa fractalis & オオシラナミアツバ & 26 & 0.004 & $19-25^{\mathrm{b})}$ & larger \\
\hline Helcystogramma triannulellum & イモキバガ & 22 & 0.004 & $15-20^{\mathrm{c})}$ & larger \\
\hline Pieris rapae & モンシロチョウ & 21 & 0.004 & $35-45^{\mathrm{e})}$ & much larger \\
\hline Anorthoa angustipennis & ホソバキリガ & 20 & 0.003 & $36-42^{\mathrm{b})}$ & much larger \\
\hline Parapediasia teterella & シバツトガ & 20 & 0.003 & $14-20^{\mathrm{d})}$ & larger \\
\hline Lycaena phlaeas & ベニシジミ & 15 & 0.003 & $25-35^{\mathrm{e})}$ & much larger \\
\hline Helicoverpa armigera & オオタバコガ & 14 & 0.002 & $29-39^{\mathrm{b})}$ & much larger \\
\hline Niphonyx segregata & チャオビヨトウ & 14 & 0.002 & ca. $32^{\mathrm{b})}$ & much larger \\
\hline Agrotis segetum & カブラヤガ & 12 & 0.002 & $38-40^{b)}$ & much larger \\
\hline Atrachea nitens & ギシギショトウ & 9 & 0.002 & $35-42^{\mathrm{b})}$ & much larger \\
\hline Mythimna separata & アワヨトウ & 8 & 0.001 & $36-42^{\mathrm{b})}$ & much larger \\
\hline Paragabara flavomacula & キボシアツバ & 8 & 0.001 & $c a .23^{\mathrm{b})}$ & larger \\
\hline Spodoptera depravata & スジキリヨトウ & 8 & 0.001 & $25-32^{\text {b) }}$ & much larger \\
\hline Herpetogramma luctuosale zelleri & モンキクロノメイガ & 7 & 0.001 & $22-26^{\mathrm{d})}$ & larger \\
\hline Mamestra brassicae & 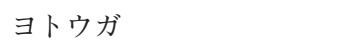 & 7 & 0.001 & $39-49^{\text {b) }}$ & much larger \\
\hline Mythimna loreyi & クサシロキヨトウ & 7 & 0.001 & $33-40^{\mathrm{b})}$ & much larger \\
\hline Sesamia inferens & イネヨトウ & 7 & 0.001 & $24-31^{\text {b) }}$ & much larger \\
\hline Pseudozizeeria maha & ヤマトシジミ & 6 & 0.001 & $20-30^{\mathrm{e})}$ & much larger \\
\hline Xylena formosa & キバラモクメキリガ & 6 & 0.001 & $47-55^{\mathrm{b})}$ & much larger \\
\hline Endotricha kuznetzovi & キモントガリメイガ & 5 & 0.001 & $15-21^{\mathrm{d})}$ & larger \\
\hline
\end{tabular}

a) Only species with total captures of $\geq 5$ at traps for $P$. xylostella were listed

b, c, d, e) Values were shown with reference to Kishida (ed.) (2011) , Hirowatari et al. (ed.) (2013) $)^{\text {c) }}$, Nasu et al. (ed.) (2013) ${ }^{\text {d) }}$, or Enju (ed.) (2013) ${ }^{\text {e) }}$

ガ用トラップに有意に多く捕獲され，コナガ用トラップ には他と比較して少ない個体数が捕獲された。コナガ以 外の 5 種の標的種はいずれもそれぞれの種用のフェロモ ン剂を使ったトラップに有意に多く捕獲された. Table 1 に示した種のうち Table 2 に示さなかった種は, いずれ もコナガ用のトラップに有意に多く捕獲されたわけでは なかった。

すべての調査地点でコナガ用トラップに有意に多く捕 獲された種のうち，コナガと大きさが似通っている種の 捕獲消長をコナガの捕獲消長と一緒に Fig. 1 に示した. コナガは調査期間を通してみると, 最も多く捕獲された 場合が多かったが, 特に近くでネギやタマネギが栽培さ れていた年があった調査地 D（大仰）では 4 月下旬から 6 月上旬にかけてネギコガが極めて多数捕獲された。

\section{考察}

本研究では, コナガ, ネギコガ, チビツトガ, ヘリグ ロホソハマキモドキ, クロミミキリガ, ミツボシキリガ, ホソバキリガの 7 種がすべての調査地点で有意に多くコ ナガ用トラップに捕獲されたことから，コナガ用フェロ モン剂に特異的に誘引されたと判断された。 クロネハイ イロヒメハマキとギシギショトウも一部の調査地点で有 意に多く捕獲されたので, コナガ用フェロモン剂に特異 的に誘引された可能性があるが, 詳細は今後の検討課題 である.オオシラナミアツバは，捕獲された個体のほと んどが限られた調査地点で一部の日に捕獲されたので, 誘引されたのではなく, トラップの近くで発生したもの が機会的に捕獲されたものと推察される.

豊嶋（2010）が報告した以外に本研究でコナガ用フェ 
Table 2. The numbers of the individuals of lepidopteran species at each of four survey sites that were captured at the sticky traps using the attractants for each of six lepidopteran species and the capture period of each species.

\begin{tabular}{|c|c|c|c|c|c|}
\hline Captured lepidopterans & Site A (Kusawa) & Site B (Shôdachô) & Site C (Takano) & Site D (Ônoki) & Capture period $^{1)}$ \\
\hline Plutella xylostella & 1091:12:4:10:11:10 & 2577:11:3:20:15:13 & 1652:9:0:3:12:4 & 576:9:6:6:12:11 & All year round \\
\hline Acrolepiopsis sapporensis & 289:0:1:1:0:0 & 944:0:0:0:0:1 & 456:1:0:4:0:1 & 2165:7:0:5:3:7 & All year round \\
\hline Microchilo inouei & $\mathbf{5 6 : 0 : 0 : 0 : 0 : 0}$ & 230:0:0:0 & 15:0:0:0 & 31:0:0:0 & $6 \mathrm{E}-10 \mathrm{M}$ (with 2-3 peaks) \\
\hline Glyphipterix nigromarginata & 18:0:0:0:0:0 & 31:0:0:1:0:0 & 42:0:0:0:0:0 & 3:0:0:0:0:0 & $3 \mathrm{~L}-5 \mathrm{E}$ \\
\hline Orthosia lizetta & 5: 0:0:0:0:0 & 39:0:0:0:0:0 & $5: 0: 0: 0: 0: 0$ & 33:0:0:0:0:0 & $3 \mathrm{E}-4 \mathrm{E}$ \\
\hline Eupsilia tripunctata & 70:0:0:0:0:0 & 10:0:0:0:0:0 & 19:0:0:0:0:0 & 25:0:0:0:0:0 & $1 \mathrm{E}-3 \mathrm{M}$ \\
\hline Rhopobota naevana & $2: 0: 0: 0: 0: 0$ & 48:1:0:0:1:0 & 0:0:0:0:0:0 & 0:0:0:0:0:0 & $6 \mathrm{~L}-7 \mathrm{~L}, 10 \mathrm{M}-11 \mathrm{M}$ \\
\hline Hipoepa fractalis & 1:0:0:0:0:0 & $0: 0: 1: 1: 0: 0$ & 0:0:0:0:0:0 & 25:0:0:0:0:0 & $8 \mathrm{E}-10 \mathrm{~L}$ \\
\hline Anorthoa angustipennis & 3:0:0:0:0:0 & 8:0:0:0:0:0 & 3:0:0:0:0:0 & 6:0:0:0:0:0 & $3 \mathrm{E}-4 \mathrm{M}$ \\
\hline Atrachea nitens & 1:0:0:0:0:0 & $6: 0: 0: 0: 0: 0$ & $0: 0: 0: 0: 0: 1$ & 1:0:0:0:0:0 & $6 \mathrm{E}-6 \mathrm{M}$ \\
\hline Parapediasia teterella & 15:3950:79:25:77:23 & 1:1718:18:4:9:2 & $0: 627: 0: 1: 0: 1$ & $4: 645: 0: 2: 1: 0$ & $4 \mathrm{~L}-11 \mathrm{M}$ (with three peaks) \\
\hline Helicoverpa armigera & 13:2696:0:1:1:0 & 1:1631:0:0:1:0 & 1:1136:0:0:1:0 & 0:181:0:0:0:0 & $4 \mathrm{~L}-12 \mathrm{E}$ \\
\hline Helicoverpa assulta & 0:0:313:0:0:0 & 0:0:602:0:0:0 & 0:0:53:0:0:0 & 0:0:104:0:0:0 & $5 \mathrm{~L}-11 \mathrm{E}$ \\
\hline Mamestra brassicae & 1:0:0:1439:0:0 & $4: 2: 0: 1613: 1: 1$ & 0:0:0:561:1:0 & 2:0:0:830:1:0 & $3 \mathrm{~L}-6 \mathrm{E}, 9 \mathrm{E}-10 \mathrm{~L}$ \\
\hline Autographa nigrisigna & 1:1:0:0:1277:0 & 0:0:0:0:1630:0 & 0:0:0:0:1278:0 & 0:0:0:1:305:0 & All year round \\
\hline Spodoptera litura & $52: 3: 2: 10: 19: 8743$ & $46: 0: 0: 3: 10: 8414$ & $28: 1: 0: 0: 2: 6331$ & $14: 7: 2: 13: 9: 5632$ & $4 \mathrm{M}-12 \mathrm{M}$ \\
\hline
\end{tabular}

The number n1:n2:n3:n4:n5:n6 represents the captured number at the trap for P. xylostella (n1), H. armigera (n2), H. assulta (n3), M. brassicae (n4), A. nigrisigna (n5), and S. litura (n6) in each survey site, respectively. Numbers typed in bold and in italic fonts are significant with $1 \%$ and $5 \%$ confidence level in each survey site, respectively.

1) Numbers represent month of the year, and $\mathrm{E}, \mathrm{M}$, and $\mathrm{L}$ represent the earlier, middle, and later period of the month, respectively.

ロモン剂に新たに特異的に誘引されることが明らかに なったのは, チビツトガ, ヘリグロホソハマキモドキ, クロミミキリガ, ミツボシキリガ，ホソバキリガの 5 種 である．豊嶋（2010）ではシバツトガも混入するとされ ていたが，本研究の結果を見る限り，シバツトガのコナ ガ用トラップでの捕獲は少なく，シバツトガは機会的に 捕獲されたと考えられた。

本試験では，豊嶋（2010）で指摘されていたように, コナガ用トラップにはコナガ以外に大きさが似通ってい るネギコガも多数捕獲された，ネギコガ用の誘引剤はコ ナガ用の誘引剂をもとに開発され（佐藤ら，1979），市 販されているネギコガ用の誘引剤はコナガ用の誘引剂の 構成成分のうち $(Z)$-11-Hexadecen-1-ol の比率を高くし て担体あたりの成分量を高めたものであるから（本郷, 2010)，ネギコガの混入はやむをえないかも知れない.

チビツトガ, ヘリグロホソハマキモドキもコナガ用 フェロモン剂に特異的に誘引され，大きさが似通ってお り，機械を使用した自動計数を行う場合などには問題と なる可能性がある。しかし，発生時期が限定され捕獲個 体数が多くないので，ネギコガと比較すると問題になる 機会は少ないと推察される.

同一の性フェロモン成分を共有する場合には非標的種 が混入しやすいと言われている（本郷，2010)。しかし
ながら，オオタバコガ用とヨトウガ用のフェロモン剂に は主成分の一つとして, タバコガ用のフェロモン剂には 微量成分として, コナガ用のフェロモン剂との共通成分 が含まれているにもかかわらず，才オタバコガやヨトウ ガやタバコガはコナガ用トラップにほとんど捕獲されな かった。 これらのことは，共通成分の有無だけが誘引の 特異性に影響を与えるわけではないことを示すと考えら れる。

フェロモン剂成分に微量の別成分を添加することによ り, 誘引効果が著しく阻害される事例が知られている(例 えば, Ishikawa et al., 1999).コナガとネギコガはそれ ぞれアブラナ科野菜とネギ類の重要な害虫であるので, 追加の微量成分等を検討するなどすることにより，互い に他種を誘引しない誘引剤の開発が望まれる.

\section{摘 要}

性フェロモン誘引䨩はその種特異性を利用して農業害 虫の発生予察に利用されるが，しばしば非標的種が特異 的に誘引される場合があり, 例えば機械で計数する場合 など, 発生予察における技術的な問題となる。ここでは, コナガ用発生予察用フェロモン剂を使用したときに特異 的に誘引される非標的チョウ目昆虫種に関する問題を明 らかにするため, 三重県津市内の 4 か所の野菜围場にお 
河野勝行・飯田博之・武田光能・本多健一郎：コナガ用フェロモン剂に誘引された非標的チョウ目
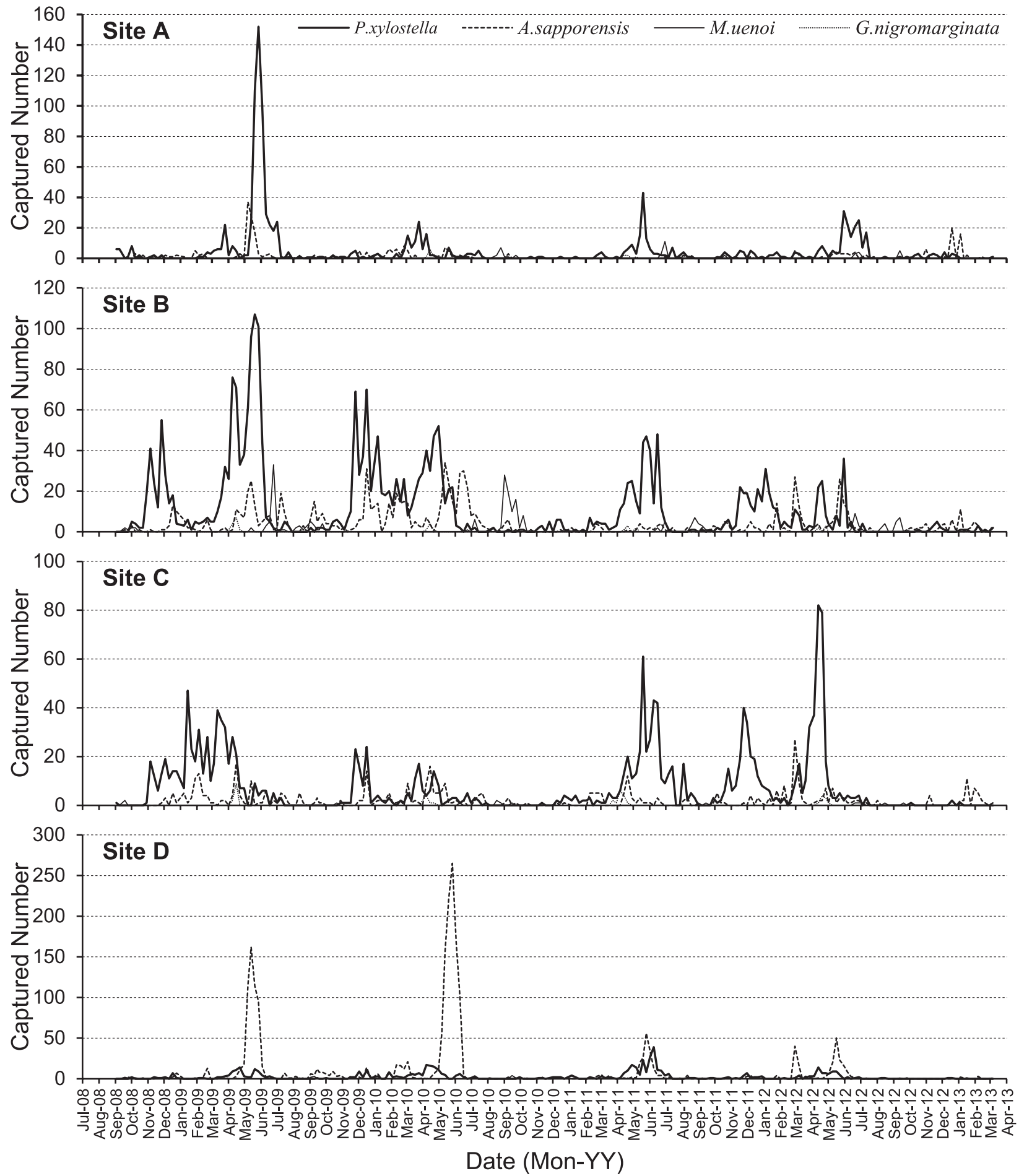

Fig. 1. Seasonal prevalence of the capture of $P$. xylostella, A. sapporensis, M. uenoi, and G. nigromarginata at the sticky trap for $P$. xylostella in each survey site.

いて調査を行った。コナガ用フェロモン剂を誘引源とし たトラップには, 標的種であるコナガのほか, ネギコガ, チビツトガ, ヘリグロホソハマキモドキ, クロミミキリ ガ, ミツボシキリガ, ホソバキリガ 6 種のチョウ目昆虫 が特異的に捕獲された。 これらのうち，コナガと発生時
期が重なり大きさが似通っているネギコガ, チビツトガ, ヘリグロホソハマキモドキが，フェロモン剤を利用した コナガの発生予察において, 自動計数を行う場合に誤認 されて問題になる可能性がある. 


\section{引用文献}

Ando, T., T. Koshihara, H. Yamada, M. H. Vu, N. Takahashi and Y. Tamaki (1979) Appl. Entomol. Zool. 14: 362-364.

槐 真史編（2013）ポケット図鑑日本の昆虫1400 1 チョウ・ バッタ・セミ。文一総合出版, 東京, pp. 20, 24, 28.

広渡俊哉・那須義次・坂巻祥孝・岸田泰則編（2013）日本産蛾 類標準図鑑 III. 学研教育出版, 東京, pp. 175, 179, 182, 299.

本郷智明（2010）植物防疫 64(13) : 6-14.

Ishikawa, Y., T. Takanashi and Y. Huang (1999) Chemoecology 9: 25-32.

Kehat, M. and E. Dunkelblum (1990) J. Insect Behav. 3: 75-83.

岸田泰則編 (2011) 日本産蛾類標準図鑑 II. 学研教育出版, 東京,

pp. 171, 218, 234, 312, 314, 324, 325, 342, 348, 351, 354, 369, 370, 374, 383, 383-384, 388.

河野勝行・飯田博之（2012a）関西病虫研報（54）：155-156.

河野勝行・飯田博之（2012b）関西病虫研報（54）：157-159.

河野勝行・飯田博之（2013）関西病虫研報（55）：101-103.

河野勝行 - 飯田博之 - 本多健一郎（2010）関西病虫研報（52）: 119-120.

河野勝行・飯田博之・武田光能・本多健一郎（2014）応動昆
$58: 343-350$.

河野勝行（2015）植物防疫 69 : 573-577.

Koshihara, T., H. Yamada, Y. Tamaki and T. Ando (1978) Appl Entomol Zool 13: 138-141.

那須義次 - 広渡俊哉・岸田泰則編（2013）日本産蛾類標準図鑑 IV. 学研教育出版, 東京, pp. 255-256，328，377，390391, 433, 438.

佐藤力郎・柳沼 薰・熊倉正昭（1979）応動昆 23: 115-117.

Sugie, H., K. Kawasaki, S. Nakagaki and N. Iwata (1991a) Appl. Entomol. Zool. 26: 71-76.

Sugie, H., S. Tatsuki, S. Nakagaki, C. B. J. Rao and A. Yamamoto (1991b) Appl. Entomol. Zool. 26: 151-153.

杉江 元・野口 浩・清水喜一・河名利幸・福田 寛・山本 昭・福本毅彦・井原俊明（1993）ヨトウガの誘引剤. 特開 平5-255009.

Tamaki, Y., K. Kawasaki, H. Yamada, T. Koshihara, N. Osaki, T. Ando, S. Yoshida and H. Kakinohana (1977) Appl Entomol Zool 12: 208-210.

豊嶋悟郎（2010）植物防疫64（13）：70-73.

Yushima, T., Y. Tamaki, S. Kamano and M. Oyama (1974) Appl. Entomol. Zool. 9: 147-152. 